\title{
South-to-south exchanges in understanding and addressing natural resource conflicts
}

\author{
Kate A. Berry $^{1}$, Bhanumathi Kalluri $^{2}$ and Antonio La Vina ${ }^{3}$
}

\begin{abstract}
Conflicts over natural resources affect millions of people in developing countries. Because they vary in terms of context, intensity, interactions between parties, and local and international implications, natural resource conflicts have different potential for transformation. Exchanges that involve communication, learning, and network development between individuals or groups in different countries within the Global South, what we call south-to-south exchanges, may have the potential to enhance capacities in addressing natural resource conflicts. Yet these types of interactions between parties in different southern countries that influence natural resource conflicts receive little consideration, although they may help in transforming conflicts, developing capacity, and contribute to resilience. CoCooN and CCMCC initiatives were designed to contribute to evidence-based policy development and practices in developing countries and an important aspect of this may be the potential to influence and enhance South-to-South communication, learning, and networks. We examine south-to-south exchanges within the $13 \mathrm{CoCooN}$ and CCMCC projects to identify situations that led to these exchanges and better understand their value. We are interested in the amount and types of south-to-south exchanges and broadly look for patterns and insights that would contribute to better exchanges in the future.
\end{abstract}

Key Words: climate change adaptation; conflict transformation; Global South; natural resources; south-to-south exchanges

\section{INTRODUCTION}

Conflicts over natural resources affect millions of local communities and a range of other actors, including resource users, beneficiaries, and public and private stakeholders in a variety of ways. Because they vary in terms of context, intensity, interactions between parties, and local and international implications, natural resource conflicts have different potentials for transformation (Frerks et al. 2014; Fisher, Bavinck, and Amsalu, unpublished manuscript). With this in mind, the Netherlands Organisation for Scientific Research (NWO) initiated a program in 2009 on the Dynamics of Cooperation and Conflicts over Natural Resources, which is referred to as $\mathrm{CoCooN}$. A goal of $\mathrm{CoCooN}$ was to contribute to usable knowledge and evidence-based policy, interventions, and practices so that natural resources benefit rather than detract from sustainable development and poverty reduction efforts. With the notion that natural resource conflicts reflect changing circumstances and that conflicts may instigate a wide range of effects, from positive to negative and everything in between (Keen et al. 2005), CoCooN intentionally addressed conflict transformation as well as cooperation in ways that were multifaceted and far from simple (Frerks et al. 2014). Conflict transformation is significant, as noted by Jeong (2010), because "transformative approaches to conflict draw our attention to such issues as the empowerment of marginalized groups and the fact that most conflicts are asymmetrical; in particular, the outcome of a conflict is often affected by power imbalances."

Developed as a joint program of the Dutch Department of Foreign Ministry and NWO, CoCooN funded multiyear projects based on their relevance for development; scientific quality and potential for innovation; and collaboration and capacity building (Frerks et al. 2014). Projects eligible for funding involved consortiums made up of academic researchers in conjunction with technical experts, practitioners, and policy makers from the private sector, nongovernmental organizations, and/or government agencies. The idea was for both southern and northern organizations to be involved as well as both research and nonresearch organizations to participate in each CoCooNfunded project (Kessler et al. 2014). Indeed, projects were expected to have a high degree of representation from the Global South, at least $50 \%$. Six projects were funded in the original CoCooN initiative and each was completed in (or before) 2016. In 2013 a second research program within CoCooN was initiated by NWO in conjunction with the Department for International Development (DFID) of the United Kingdom (UK) to focus on a better understanding of the dynamics of cooperation and/or conflict around managing climate change, otherwise known as CCMCC. Seven projects were funded in the CCMCC initiative, each of which has completed a midterm review but is still ongoing.

Of particular relevance in this article are that $\operatorname{CoCooN}$ and CCMCC projects could facilitate communication, learning, and networks between individuals and organizations from different countries in the Global South, what we refer to here collectively as south-to-south exchanges. Increased attention to capacity development in the north has lent greater significance and visibility to interactions between individuals within the south. There is the possibility of leveraging such interactions for more effective capacity development, which may also increase the impact of north-south capacity building. An example of a comprehensive and coordinated alliance that is premised on the value of south-to-south exchanges in dealing with natural resources is the International Alliance on Natural Resources in Africa, which according to its web site, includes 41 nongovernmental and community-based organizations from 13 African countries (and the Netherlands), for the purpose of "community organising, research, and evidence-based advocacy to collectively strive for more just and sustainable use of natural resources that can lead to more inclusive development in Africa" (http://ianra.org/).

To be clear, our analysis does not intend to be global in reach, nor are we focused on more permanent assemblages, such as the

${ }^{1}$ University of Nevada, Reno, USA, ${ }^{2}$ Dhaatri - A Resource Centre for Women \& Children's Rights, India, ${ }^{3}$ Ateneo de Manila University School of Government, Manila, Philippines 
International Alliance on Natural Resources in Africa. We also distinguish our focus here from many programs and analyses on south-to-south cooperation that focus on macroscale political economic transactions with representatives and institutions at the country-to-country level (Gray and Gills 2016, UN Office for South-to-South Cooperation 2017). Instead, we are interested in better understanding where and how south-to-south exchanges occur in civil society, as individual and organizational exchanges within the context of development projects and international research.

These types of interactions between different academic and nonacademic practitioner constituencies in different countries tend to receive less consideration than north-to-south exchanges, yet south-to-south exchanges may contribute in novel and more effective ways to transforming conflicts related to natural resources. We believe that south-to-south exchanges may increase the potential for transformative change because they offer opportunities to build trust, change power dynamics through creative strategies and interventions, and explore different visions of social relations (Papastergiadis 2017). Although it would be naïve to suggest that all south-to-south exchanges address marginalization (Papastergiadis 2017) or will necessarily lead to environmental conflict transformation in the South, these exchanges may result in different approaches to address power dynamics, increase resiliency, and respond to the increasing involvement and conflicting mandates of global assemblages, which are often composed of multinational corporations, lending organizations, and other northern-centric governance structures (Ogden et al. 2013). We have drawn from recent work on capacity development in the south, although we do not concern ourselves here specifically with the north-to-south transfer of ideas, processes, or funds (Vallejo and Wehn 2016).

Although south-to-south interactions were not a primary objective of the CoCooN and CCMCC initiatives, they did occur, albeit perhaps not as deliberately planned south-to-south exchanges but as part of the project planning and strategizing processes between the northern and southern partners. Therefore north-to-south exchanges were intentionally designed in the CoCooN and CCMCC conceptualization, and south-to-south exchanges emerged as a positive necessity through project working arrangements, like workshops and conferences, although not as discernibly. We observe this as a valuable outcome of the $\mathrm{CoCooN}$ and CCMCC processes of Global South exchanges.

Although such exchanges may facilitate interdisciplinary learning and the development of expertise in conflict theory, strategies, and practices, our aims in this article were necessarily modest because of the type of exchanges and sources available to us. We initiated this study to learn more about the extent and types of these types of exchanges and broadly look for patterns and insights. Although there is little written about such research and development exchanges between southern partners, we have been informed by recent work about the increasing significance of communications, networks, and leadership in environmental governance (Lincklaen Arriëns and Wehn Montalvo 2013, Cheema and Khan 2016, Berry 2017, Delfau 2017). We examine south-to-south exchanges at the level of person-to-person and organization-to-organization for $13 \mathrm{CoCooN}$ and CCMCC projects to broadly understand the nature and character of such exchanges. We hope that this study will initiate more awareness, prompt more interdisciplinary research, and build on the experiences from these projects to strengthen more conscious approaches to promote south-to-south exchanges.

\section{METHODS}

In this analysis we relied on the definition of southern countries used in the CCMCC call-for-proposals: "southern countries include all low and middle-income countries that qualify for receiving Official Development Assistance (ODA), as defined by the OECD (see http://www.oecd.org/development/stats/ daclistofodarecipients.htm)" (NWO 2012:2).

South-to-south exchanges in $\mathrm{CoCooN}$ and $\mathrm{CCMCC}$ projects often were not deliberately sought out or even recorded. There is no complete nor systematic record of all south-to-south exchanges; even within a project, all such exchanges were not recorded to our knowledge. However, our analysis of south-tosouth exchanges within the CoCooN and CCMCC programs is drawn from the extensive records available from the 13 different projects maintained by the teams at different points of their respective project cycles.

Our approach to identify such exchanges was to look for flows of information between individuals and organizations based in the south as well as look for the international output from individuals and organizations, such as publications, presentations, films, and web sites. For each of the CoCooN projects we reviewed the following materials that were available: project proposals, midterm self-assessment reports, final self-assessment reports, final review reports, publications, web sites, and films. There was less material for the CCMCC projects because they are ongoing so we reviewed the following materials as they were available: project proposals, midterm self-assessment reports, midterm external review, publications, web sites, and films. Although everything about each project is not visible in these reports, these materials did cover many aspects over a period of years for each project. Consequently, our analyses are partial and qualitative in the sense that we examined materials from the projects for information, patterns, and insights on south-to-south exchanges, rather than with the goal of developing concrete or quantitative analyses.

We organized the materials about research and development approaches and practices as well as other information exchanges in $\mathrm{CoCooN}$ and CCMCC around two categories: flow of information and international output. Although our focus in using two categories was to analyze exchanges as a means of communication, we also included information about networks and leadership where such information was available. Flow of information includes movement of people, ideas, practices, and information from one southern country or institution to another southern country or institution. International output includes publications, networking, policy level lobbying strategies, and other materials for the public produced by southern graduate students, postdoctoral scholars, faculty or others with those from other southern countries. Table 1 provides a list of the CoCooN and CCMCC projects and shows the affiliation of team members as listed in the project proposal. 
Table 1. CoCooN and CCMCC Projects. Project number, project name, countries of the team members. ${ }^{\dagger}$

\begin{tabular}{|c|c|c|}
\hline 1 & $\begin{array}{l}\text { Assessing the socioeconomic implications of industrial biofuel plantations: repercussions } \\
\text { of Jatropha curcas on rural land use alienation and conflict escalation. }\end{array}$ & Canada, Ethiopia, Ghana, Netherlands \\
\hline 2 & Groundwater in the political domain. & Ethiopia, Netherlands, Palestine, Yemen \\
\hline 3 & $\begin{array}{l}\text { Land and rights in troubled waters: land use change, environmental harm, and human } \\
\text { rights violations. }\end{array}$ & Brazil, Colombia, Germany, Netherlands \\
\hline 4 & Nationalization of extractive industries, conflict and cooperation. & Bolivia, Ecuador, Netherlands, USA \\
\hline 5 & $\begin{array}{l}\text { Reincorporating the excluded: providing space for small-scale fishers in the sustainable } \\
\text { development of fisheries. }\end{array}$ & India, South Africa, Sri Lanka, Netherlands, UK \\
\hline 6 & $\begin{array}{l}\text { Small-scale gold mining and social conflict in the Amazon: comparing states, environments, } \\
\text { local populations, and miners. }\end{array}$ & $\begin{array}{l}\text { Bolivia, Brazil, Canada, Colombia, Netherlands, } \\
\text { Suriname, Peru }\end{array}$ \\
\hline 11 & $\begin{array}{l}\text { Climate change mitigation policies, land grabbing \& conflict in fragile states: } \\
\text { Understanding intersections, exploring transformations. }\end{array}$ & $\begin{array}{l}\text { Cambodia, Indonesia, Myanmar, Netherlands, } \\
\text { Philippines, Spain, Thailand, UK, USA }\end{array}$ \\
\hline 12 & $\begin{array}{l}\text { Climate policy, conflicts, and cooperation in peri-urban South Asia: toward resilient and } \\
\text { water secure communities. }\end{array}$ & Bangladesh, India, Nepal, Netherlands \\
\hline 13 & Community-based adaptive learning in management of conflicts and natural resources. & Bangladesh, Nepal, UK, USA \\
\hline 14 & Conflict and cooperation over REDD+. & Mexico, Nepal, Thailand, UK, USA, Vietnam \\
\hline 15 & $\begin{array}{l}\text { Hydropower development in the context of climate change: exploring conflicts and } \\
\text { fostering cooperation across scales and boundaries in the eastern Himalayas. }\end{array}$ & India, Nepal, Netherlands, Turkey, UK \\
\hline 16 & $\begin{array}{l}\text { Investing in land and water: turning new climate finance mechanisms into tools for } \\
\text { cooperation. }\end{array}$ & Ethiopia, Indonesia, Netherlands \\
\hline 17 & Toward more inclusive, cooperative, and participative climate change interventions. & $\begin{array}{l}\text { Burkina Faso, Denmark, Ghana, Kenya, Mali, } \\
\text { Netherlands }\end{array}$ \\
\hline
\end{tabular}

\section{RESULTS AND DISCUSSION}

\section{Flow of information}

\section{Program-wide exchanges}

A series of workshops and conferences were sponsored by NWO that brought together team members from various projects in November 2013, January 2014, December 2015, and April 2016. Often these events were attended not only by project team members, but by an array of people interested or working with CoCooN and CCMCC. An aspect of these workshops and conferences was a formal venue to present info about their own projects to a broad array of people, both those from southern and those from northern countries, as well as to learn about other CoCooN and CCMCC projects. There were also informal venues to talk one-on-one with people from other southern countries about the project they were involved in. For instance, at one event team members from project 2 had a productive exchange about water grabbing with team members from project 3 . As well, team members from projects 4 and 6 noted exchanges of information during the first half of their projects because both projects overlapped on one southern country (Bolivia) and shared a focus on mining conflicts in Latin America. In a number of cases, project teams used the NWO-sponsored events as an opportunity to have other meetings within their own projects and work with their team members on the project. Often, however, these facilitated north-to-south exchanges more so than south-to-south exchanges. For instance, while in the Netherlands at the CoCooN and CCMCC-wide events, certain projects took the opportunity to lobby or share information with Dutch companies, ministries, and universities through arranged meetings, presentations, or organizing workshops.

In addition to hosting and funding initiative-wide meetings, NWO also made available a specialist to help projects in the CCMCC program effectively handle gender issues in their projects. As a result, the consultant (from a northern country) served as a conduit of information to teams in dealing with gender issues in southern countries. Viewing gender as a cross-cutting issue, team members of project 13 sought assistance from the gender specialist in developing a strategy to deal with women's participation in transforming natural resource conflicts. This consultation led team members in both Bangladesh and Nepal to decide it was important to assess the levels and conditions associated with women's participation. A bit later in their project, this team intends to collaborate with other CCMCC projects on cross-cutting issues, such as gender. Team member from project 11 also anticipated working on gender issues, with the goal of putting together a special issue of the Journal of Peasant Studies on gender, generation and agrarian-environmental transformations in Southeast Asia.

\section{Within-project exchanges}

Each project had a kick-off meeting or early workshops, which in some cases were used to develop the proposal and in other cases came after funding was awarded. Project 4 , for example, started off with three workshops in 2010 to refine their proposal, holding one workshop in Ecuador, one in Bolivia, and one in the Netherlands. In many cases, project participants from various countries came together in one location so that south-to-south exchanges of information related to their joint project could be possible. For example, in project 1, team members met in February 2010 in Africa for a planning workshop to work through the proposal and project. Most projects had regular meetings (often annually) in which team members from southern countries worked with another one and made joint decisions. In project 11, for instance, early on the team decided to refocus the project on two of the originally proposed four countries so more resources could be made available for research and development in the fragile states of Myanmar and Cambodia. Nevertheless, team members from two other southern countries, Indonesia and the 
Philippines, remained involved in the project by participating in the annual knowledge-sharing workshops. Another example comes from project 15 in which a discussion between team members from India and Nepal about the emerging challenges and complexities in the eastern Himalayas was successful enough that it was followed some months later by a "summer school," an opportunity for training and exchanges that brought together a broad group of team members from research and civil society organizations from all eight participating organizations in five countries.

In other cases meetings or workshops held by the project in one country informed the development of later meetings or workshops in other countries. In project 5, for instance, team members used themselves and their resources to mediate and inform parties involved in conflict and to facilitate initiatives in self-governance in 2011 in India. Similar stakeholder workshops organized in Sri Lanka reflected some of what had been learned in India. For project teams who initially had lofty ambitions, which included numerous trips, meetings, workflows, and communications planned between southern team members, they frequently found these did not happen often or happened only because they were orchestrated by a northern team coordinator. Yet one-to-one interactions between the northern researchers and southern partners also allowed for some introductions between southern groups or individuals that addressed similar conflicts. So even when there were apparently fewer opportunities for interchange, when within-project meetings did happen, they contributed significantly in terms of south-to-south exchanges.

\section{Fieldwork exchanges}

In some projects other types of face-to-face interactions were specifically built into the project design. Project 17, for example, set up exchanges between farmers in Ghana and Kenya to discuss farming under changing climatic conditions. Farmers of one community were taken to speak with farmers from a community that currently has the climatic conditions that the target community is expected to have in the future. There were also occasions when ideas and information about practices were exchanged between one southern team member and another on the same project. An example is project 1 where team members from Ghana decided to adopt an approach from Ethiopia "on contract farming and how it was used as a strategy to reduce conflict between communities and investors..." (Final SelfAssessment Review Report:21) and these kinds of exchanges "led to some insights being shared across the two countries ... on smallholder production, local value added, and agroforestry ..." (Final Review Report:15). In the case of project 14, team members jointly developed a shared research protocol with a theoretical framework, research methodology, and plan as well as did fieldwork in one another's countries. Team members from Nepal joined fieldwork in Mexico and team members from Mexico joined fieldwork done in Vietnam. Similarly in project 16, Indonesian team members went to field sites in Ethiopia to compare initial findings and vice versa. Project leaders reported this as contributing to broadening everyone's perspectives. For project 6 , multiple field visits made to mining regions allowed southern researchers and other team members to "see with their own eyes the differences and similarities with regards to smallscale gold mining in a different locality. It triggered dialogues that proved to be extremely useful for our common understanding"
(Final Review:7). At times, however, events changed a project or set it back in ways that made direct exchanges between southern countries more challenging. In April 2015 Nepal experienced a major earthquake followed by limited transportation and shortages of fuel and food. This influenced the potential for southto-south exchanges through fieldwork or meetings for projects 12 , 13 , and 15 , because movement across Nepal's border from India and Bangladesh was restricted.

\section{Educational exchanges}

Education was another means through which south-to-south communications, learning, and networks were developed. Although university students at various levels were funded through $\mathrm{CoCooN}$ and $\mathrm{CCMCC}$ projects, we found that most of the students studied at institutions within their own countries, with the exception of a number of Northern graduate students who often studied abroad in a southern country. In project 2 , for example, five Dutch students worked on the project in Palestine, five Dutch and one Ethiopian student studied in Ethiopia, and three Yemeni students studied in Yemen (all from Yemen). Still, limited south-to-south exchanges that involved university students were noted as occurring. Project 6, for example, noted that about 10 graduate students studying issues associated with small-scale gold mining at various institutions in South America were attracted to the network that the project had established, even though no funding through this program was offered to them. As such the projects occasionally attracted students who were not supported by $\mathrm{CoCooN}$ or CCMCC funding to their project activities.

\section{Web sites and electronic exchanges}

Projects had a number of other strategies for their internal flow of information that facilitated south-to-south exchanges. Internal communications often relied on the increasing availability of a variety of electronic technologies. For example, team members from both projects 14 and 16 used email, skype, one-on-one calls, and cloud storage (Dropbox and Google Drive) as ways to stay in touch, convey relevant news and information, and share work products. Some projects developed web sites as well. Project 14 has a web site that introduces the project and discusses the countries involved, Mexico, Nepal, and Vietnam (https://www. recoftc.org/project/cocoor). The team for project 6 developed a web site and made it accessible in four languages, Spanish, Portuguese, English, and Dutch, which can facilitate both current and future south-to-south exchanges (http://www.gomiam.org/). The web site of another CoCooN project (\#5) includes links to many different types of international output, including journal articles, reports, theses, newspaper stories, policy briefs, letters to policy makers, and films (http://www.reincorpfish.info/). Seventyfour documents and other materials are linked to this web site, many of which discuss fishing conflicts between Sri Lankans and Indians. However, none of these address connections or insights between South Africa and South Asia, except for a chapter in the CoCooN book (Bavinck et al. 2014).

\section{Observations and implications}

Overall, we observe that although south-to-south exchanges involving flow of information occurred within the projects, they were not widespread and systematic. Such exchanges were more opportunistic than planned. More often than not, project work was organized separately within each country, with occasional 
work coordination that allowed for meaningful exchanges between team members in different southern countries. Another practice that reduced south-to-south exchanges was that coordination of project work was most often from a northern country, as indicated by who was listed as principal investigator (PI) or was responsible for the reporting to NWO. The effect was to mediate direct information flows between team members from southern countries. Thus, in most cases the northern PI/ coordinators' ideas and actions set the stage for the potential diversity, number, and value of south-to-south exchanges, rather than direction and information coming from a southern team member(s). In the future, it might be important to designate a coordinator from a southern country as specifically responsible for the south-to-south exchanges.

Although many of the project teams targeted research and policy recommendations for natural resources and/or climate change in national contexts, some recognized the limitations of the national level and consciously expanded or contracted their sphere of influence. Project 12, for instance, recognized that national environmental policies often did not make provisions for climate change, which could lead to conflicts. On the other hand, looking to build on south-to-south exchanges, team members of project 11 plan to investigate grassroots and civil society initiatives that use global instruments to settle and transform conflicts within and outside Southeast Asia; link the project's grassroots and civil society partners to networks (if they are not yet linked); and support their beyond-national advocacy work. Additionally, project 6 sees its network as having transnational potential as a regional player in addressing small-scale mining issues. This is because the project has evolved into a recognized network of academics, practitioners, miners' organizations, and policy makers working on issues related to small-scale mining in the Amazon. Without this project, the team feels that most of the research and capacity development related to this theme would not have taken place, the knowledge platform developed over the past five years would not exist, and exchanges between stakeholders throughout the region would not have happened.

\section{International output}

Dozens of publications were produced by the CoCooN and CCMCC projects and more are still being prepared. These include journal articles, reports, book chapters, as well as a book specific to CoCooN. Additionally, some films and maps were produced and many conference presentations were made. Here we focus on the international output that brought together individuals from two or more southern countries as coauthors as a form of southto-south exchanges and also make note of output that concerned itself about issue(s) in more than one southern country, regardless of authorship.

\section{Exchanges through authoring publications}

In terms of the many dozens of publications produced by projects in the CoCooN program, a journal article from project 1 had Ghanaian and Ethiopian coauthors, along with a Canadian lead author. Project 2 produced a book chapter with 10 coauthors, including $\mathrm{PhD}$ students, professors, and water resources professionals from Netherlands, Ethiopia, Yemen, and Palestine in a joint book on CoCooN. Project 5 produced a book chapter coauthored by professors from the Netherlands, South Africa, and India. Project 6 produced a book chapter with coauthors from the Netherlands, Suriname, Colombia, and Brazil. The CCMCC projects have fewer publications at this point because they have yet to complete their work. However, it is clear that in terms of their plans, as with the CoCooN projects, there are not many publications being planned that include authors from multiple southern countries. More often it seems the focus is on analyzing countries and publishing analyses separately rather than comparatively or transnationally.

Some publications produced by $\mathrm{CoCooN}$ and CCMCC projects are of note because they address multiple countries from the south in different ways. For instance, team members from project 1 were involved with a specially themed journal issue, which included one team member as a coeditor along with three articles produced from the project. Thus, their work was placed in a journal issue that included research from many other countries in the south from other projects. In another project (\#17) a book, still in the planning phase, is proposed to cover three different African countries, but will only be coedited by Dutch and Ghanaian researchers. A book on CoCooN by Bavinck et al. (2014) included a chapter from each of the $\mathrm{CoCooN}$ projects, thus bringing all of the projects, along with the southern countries and chapter authors, together within a single volume. In addition to peerreviewed publications, other materials were designed to be useful for international policy making, advocacy, and education. Project 3 , for example, developed a number of such publications, some reports providing information or lobbying tools for international organizations including agencies with the United Nations and Organization of American States.

\section{Exchanges through developing presentations}

Many presentations resulted from the $\mathrm{CoCooN}$ and CCMCC projects. At times an entire session at a conference focused on one of the projects. For instance, in May 2016 team members from project 12 made presentations at their own session at the Fourth Annual International Climate Change Adaptation Conference. The session, centered on the CCMCC project, was chaired by a researcher from a Dutch institution and had one presentation centered on research in Bangladesh by Bangladeshi team members, one presentation centered on research in Nepal by Nepali and Dutch researchers, and one presentation centered on India from an Indian NGO representative. This type of parallel venue, in which team members from different countries made separate contributions under an overarching project-wide (or initiative-wide) umbrella seems to be common for the CoCooN and CCMCC projects.

\section{Exchanges through producing films and webinars}

A number of the projects produced English-language films that are available online (often on YouTube). Films varied in length and complexity. Most films, however, only assessed a single country, such as project 1 that produced two short films, each focused on a single country. However, in a few instances films were made to cover the issues faced by more than one southern country, as was the case in project 3 . Project 2 also produced a short film that described two of the three countries in their project but not comparatively, although there was a brief discussion of research/ applied policy interface. Project 2 also filmed a webinar that, among other things, made comparisons between two countries in the study. This webinar was also placed on the Water Channel TV so it could be accessed long after the project's completion. In the 
case of films, a number of mostly short films produced on/by CoCooN projects were placed on the Water Channel TV website, which has a wide variety of international coverage. This allows viewers to independently find information and insights from multiple southern countries, should they be so inclined to do so, but not in a systematic or comparative fashion.

\section{Observations and implications}

Project 6 reflected on the value of having researchers and nonresearchers from various southern and northern countries contribute to international output:

\begin{abstract}
The project team includes partners from both research and non-research institutions, in the north as well as in the south, and within the five country teams. The difference between researchers and non-researchers is rather blurred, which is felt as a positive element, as they all contribute to the project and to research in their own way. The interaction between the different partners is positive and there are many examples of useful exchange of information, synergy, learning from each other and new emerging institutional arrangements (Midterm SelfAssessment Report:3).
\end{abstract}

Nonetheless, we find that to date most of the international output did not involve south-to-south exchanges, although many resulted from north-to-south exchanges. Additionally, very few publications or other output from the $\mathrm{CoCooN}$ and CCMCC projects engaged with issues in multiple southern countries through transnational, comparative, or other systematic approaches to research. Project 4, for instance, lists 33 publications in the Final Self-Assessment Report as directly or indirectly resulting from the project. Of these 33 publications, eight publications were submitted, are in press, or were otherwise unavailable for review, leaving us with 25 publications to review. Only two of these publications (8\%) involved south-to-south exchanges in publication with (co)authors from multiple southern countries. All the rest have either only northern (co)authors, northern plus one southern (co)authors, or only author(s) from a single southern country. Additionally, an assessment of the publication titles and abstracts of all 33 publications suggest only four of them $(12 \%)$ assessed topics from both of the Southern countries involved in the project, Bolivia and Ecuador. Although not all the CoCooN and CCMCC projects have (or will have) as many publications resulting from their project, this finding reflects the trend of other projects as well: in the materials we analyzed it is the exception rather than the rule for there to be south-to-south exchanges in international output, whether in terms of collaborations in coauthoring publications or in terms of publications that addressed issues across multiple southern countries. More opportunities for academic exchanges and joint communications between team members from different southern countries might have included more cross-cutting publications, presentations, and films along with the opportunities to work and publish among southern team members from different places.

\section{CONCLUSIONS}

Because they were built into the design of the CoCooN and CCMCC initiatives, it was not surprising that we found more evidence of north-to-south than south-to-south exchanges in the projects. For all their innovation, these programs are north-centric in several respects. Despite bringing in both southern and northern participants in meaningful ways into the programs, such as developing an International Panel Advisory Committee, research grants originated in the north and were guided by the principles of northern government and approaches to understanding natural resource conflicts. Moreover, team coordinators were often northern-based, which influenced the type, timing, location, and other dynamics of exchanges. Generally speaking, researchers from the north have a greater array of research experience, access to more funding sources to support travel, and other advantages that allowed them to initiate, participate, or benefit from exchanges. In the future, specifically recognizing the importance of southern leadership and facilitating south-to-south exchanges through funding and other means might mitigate these tendencies.

Still, some of the strongest elements of interdisciplinary and interregional linkages in the $\mathrm{CoCooN}$ and $\mathrm{CCMCC}$ projects were research collaborations with and between southern organizations, communities, and individuals involved in natural resources and climate change-driven conflicts. The comparative geographical and strategic innovations of $\mathrm{CoCooN}$ and CCMCC initiatives suggest the prospect of making voices of dissent more audible, strengthening coping mechanisms, consolidating evidence of local innovative practices, moving forward on the basis of rationality, building networks of knowledge and solidarity, and identifying cross-cutting policy approaches; each of which may advance conflict transformation, develop capacity, or contribute to resilience. For this potential to be more fully realized, there needs to be more and greater opportunities for southern research and nonresearch institutions and deeper, more systematic, and institutionalized south-to-south exchanges. The communications, learning, and network development involved in south-to-south exchanges, especially if they enhance the capacity of institutions to carry on their work, might enhance such opportunities by forging new pathways in addressing natural resource and climate change-driven conflicts.

Our study examined the extent, types, and patterns of exchanges along with insights from exchanges relative to conflict transformation. Although the available project documentation was useful in uncovering south-to-south exchanges, it is clear that these were not a complete reporting and this is a methodological limitation of our study. Nonetheless, we were able to identify, characterize, trace some patterns, and develop insights about south-to-south exchanges. We found that NWO-sponsored workshops and conferences resulted in opportunities for southto-south exchange, both through formal presentations and events as well as informal venues for discussion and networking. These events were noted as being valuable for southern team members from different projects to interact. Additionally, regular in-person meetings and electronic communications within projects between southern team members not only made it possible for project work to get accomplished, but served both to increase the frequency and add depth to exchanges. We also found that permanent (or long-term) web sites about projects also facilitated flows of information between individuals and organizations from southern countries who were not part of the projects. Moreover, publications, presentations, and films from the CoCooN and CCMCC projects mostly involved north-to-south collaborations or authorship from a single northern or southern country, with 
only a few instances where multiple southern (co)authors collaborated. This reflected a tendency to publish materials of team members from different southern countries within a project separately, rather than in a comparative or transnational fashion. This tendency means missing opportunities for deeper exchanges between authors from different southern countries and fewer cross-cutting contributions. Sometimes separate publications centered on a single country were brought together within a single journal issue or book. Similarly, some presentations and films on individual southern countries were brought together within a single conference session or web channel, which seems to be at least a starting point for engaging south-to-south exchanges.

Joint field work between team members from different southern countries and transnational opportunities for stakeholders to travel to different southern countries was built into some of the projects. These types of south-to-south exchanges seemed to contribute to finding innovative ideas about and solutions for conflict transformation. However, there were few recorded educational exchanges where university students from one southern country went to study in another southern country. Although this partially reflects issues about the quality of higher education in some southern countries, it is also attributable to the dynamics of northern leadership prevalent in CoCooN and CCMCC projects and the built-in drive for north-to-south educational exchanges, but seems a missed opportunity. More and deeper south-to-south exchanges allowed project teams to negotiate the competing need to address local conditions with the needs to develop common methodological frameworks and share in planning and decision making. In contrast to cases where northern team member(s) dominate coordination, planning, and decision making, in these situations southern exchanges offer the prospect of more horizontal organizational structures, shared leadership, and better understanding of conflict dynamics. As such, comparative southern exchanges and southern leadership not only facilitated south-to-south exchanges, but also aided in northern understanding of southern conflict dynamics.

NWO's interest in the gendered dimensions of conflicts and making available a gender specialist for CCMCC projects inspired some project teams to see gender as a potential cross-cutting issue that could bridge southern countries within a project and possibly between projects as well. The results of focusing on a cross-cutting theme have yet to be fully developed, but offers the prospect of better facilitating conflict transformation. Moreover, some teams framed their project to have impacts beyond the national sphere. In these cases south-to-south exchanges have the potential to assume new significance within the objectives of the projects themselves. In such cases, the potential for south-to-south exchanges to contribute to conflict transformation seems particularly insightful.

Responses to this article can be read online at: http://www.ecologyandsociety.org/issues/responses. php/10306

\section{LITERATURE CITED}

Bavinck, M., L. Pellegrini, and E. Mostert, editors. 2014. Conflict over natural resources in the global south: conceptual approaches. CRC, London, UK. http://dx.doi.org/10.1201/b16498

Berry, K. A. 2017. Beyond the American culture wars: a call for environmental leadership and strengthening networks. Regions and Cohesion 7(2):90-95. [online] URL: https://www. berghahnjournals.com/abstract/journals/regions-and-cohesion/7/2/ reco070205.xml?

Cheema, A. R., and M. A. Khan. 2016. South-south learning. Global Policy. Blog. 20 October. [online] URL: http://www. globalpolicyjournal.com/blog/20/10/2016/south-south-learning.

Delfau, K. 2017. The importance of networks. International Water Association, London, UK. [online] URL: http://www.iwanetwork.org/the-importance-of-networks?/utm source=IWANetwork\&utm campaign $=7071833 \mathrm{df}$

Frerks, G., T. Dietz, and P. Van der Zaag. 2014. Conflict and cooperation on natural resources: justifying the $\mathrm{CoCooN}$ programme. Pages 13-34 in M. Bavinck, L. Pellegrini, and E. Mostert, editors. Conflict over natural resources in the global south: conceptual approaches. CRC, London, UK.

Grey, K., and B. K. Gills. 2016. South-south cooperation and the rise of the Global South. Third World Quarterly 37(4):557-574. http://dx.doi.org/10.1080/01436597.2015.1128817

Jeong, H. 2010. Conflict transformation. In N. J. Young, editor. Oxford international encyclopedia of peace. Oxford University Press, Oxford, UK. [online] URL: http://www.oxfordreference. com/view/10.1093/acref/9780195334685.001.0001/acref-9780195334685e-136

Keen, M., V. A. Brown, and R. Dyball. 2005. Social learning: a new approach to environmental management. Pages 3-21 in $\mathrm{M}$. Keen, V. A. Brown, and R. Dyball, editors. Social learning in environmental management: towards a sustainable future. Earthscan, London, UK.

Kessler, J. J., H. van Dijk, and W. van Ijssel. 2014. Challenges in the design of a research and development programme on conflict and cooperation over natural resources. Pages 193-204 in M. Bavinck, L. Pellegrini, and E. Mostert, editors. Conflict over natural resources in the global south: conceptual approaches. CRC, London, UK.

Lincklaen Arriëns, W. T., and U. Wehn de Montalvo. 2013. Exploring water leadership. Water Policy 15:15-41. http://dx.doi. org/10.2166/wp.2013.010

NWO (Netherlands Organisation for Scientific Research). 2012. CoCooN-Conflict and Cooperation over Natural Resources in Developing Countries: 2012 2nd round call for preliminary proposals. CCMCC-Conflict and Cooperation in the Management of Climate Change. Netherlands Organisation for Scientific Research, The Hague, The Netherlands.

Ogden, L., N. Heynen, U. Oslender, P. West, K.-A. Kassam, and P. Robbins. 2013. Global assemblages, resilience, and Earth stewardship in the Anthropocene. Frontiers in Ecology and the Environment 11(7):341-347. http://dx.doi.org/10.1890/120327 
Papastergiadis, N. 2017. The end of the Global South and the cultures of the south. Thesis Eleven 142(1):69-90. http://dx.doi. org/10.1177/0725513617712790

United Nations (UN) Office on South-South Cooperation. 2017. South-south cooperation. United Nations Development Programme, New York, New York, USA. [online] URL: http:// www.undp.org/content/undp/en/home/development-impact/southsouth-cooperation.html

Vallejo, B., and U. Wehn. 2016. Capacity development evaluation: the challenge of the results agenda and measuring return on investment in the global south. World Development 79:1-13. http:// dx.doi.org/10.1016/j.worlddev.2015.10.044 